\title{
Quality improvement programs and the professional nursing practice environment: an integrative review
}

\author{
Programas de melhoria de qualidade e o ambiente de prática profissional de enfermagem: revisão integrativa
}

Programas de mejoría de calidad y el ambiente de práctica profesional de enfermería: revisión integrativa

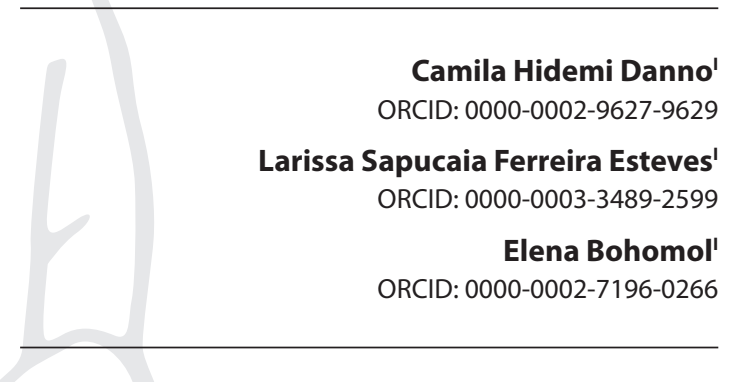

'Universidade Federal de São Paulo. São Paulo, São Paulo, Brazil.

How to cite this article:

Danno CH, Esteves LSF, Bohomol E. Quality improvement programs and the professional nursing practice environment: an integrative review.

Rev Bras Enferm. 2021;74(1):e20200108. doi: http://dx.doi.org/10.1590/0034-7167-2020-0108

\section{Corresponding author:}

Camila Hidemi Danno

E-mail: milahidemi@hotmail.com

EDITOR IN CHIEF: Antonio José de Almeida Filho ASSOCIATE EDITOR: Priscilla Valladares Broca

Submission: 04-19-2020

Approval: 08-09-2020

\begin{abstract}
Objectives: to analyze the knowledge produced regarding-the practice environment in hospitals with quality improvement programs. Methods: integrative literature review performed in the Latin American and Caribbean Literature in Health Sciences databases, US National Library of Medicine/National Institutes of Health, Web of Science, Scopus and CINAHL, consisting in 10 articles. Results: data were presented and discussed using categories: Measures for the professional nursing practice environment; Hospital accreditation as an improvement program; Nursing autonomy, interpersonal relationship between nurse and doctor and the nurse as a manager and leader. Final Considerations: it was possible to analyze that the influence of quality improvement programs can be considered as favorable in the professional nursing practice environment. The survey also brings contributions to administration in implementing strategies aiming at continuous improvement in the environment characteristics.

Descriptors: Nursing; Quality of Health Care; Accreditation; Workplace; Quality Improvement.
\end{abstract}

\section{RESUMO}

Objetivos: analisar o conhecimento produzido quanto ao ambiente de prática em hospitais que possuem programas de melhoria da qualidade. Métodos: revisão integrativa da literatura realizada nas bases de dados Literatura Latino-Americana e do Caribe em Ciências da Saúde, US National Library of Medicine/National Institutes of Health, Web of Science, Scopus e CINAHL, compreendendo 10 artigos. Resultados: os dados foram apresentados e discutidos usando-se categorias: Medidas para o ambiente de prática profissional de enfermagem; a Acreditação Hospitalar como programa de melhoria; Autonomia da enfermagem, relacionamento interpessoal entre enfermagem e médico e enfermeiro enquanto gestor e líder. Considerações Finais: foi possível analisar que a influência de programas de melhoria da qualidade pode ser considerada como favorável sobre o ambiente de prática profissional de enfermagem. O estudo também traz contribuições para a gestão na implantação de estratégias visando à melhoria contínua das características do ambiente.

Descritores: Enfermagem; Qualidade da Assistência à Saúde; Acreditação Hospitalar; Ambiente de Trabalho; Melhoria de Qualidade.

\section{RESUMEN}

Objetivos: analizar el conocimiento producido cuanto al ambiente de práctica en hospitales que poseen programas de mejoría de la calidad. Métodos: revisión integrativa de la literatura realizada en las bases de datos de la Literatura Latinoamericana y del Caribe en Ciencias de la Salud, US National Library of Medicine/National Institutes of Health, Web of Science, Scopus y CINAHL, comprendiendo 10 artículos. Resultados: los datos han presentados y discutidos usándose categorías: Medidas para el ambiente de práctica profesional de enfermería; la Acreditación Hospitalaria como programa de mejoría; Autonomía de la enfermería, relación interpersonal entre enfermería y médico y enfermero como gestor y líder. Consideraciones Finales: ha sido posible analizar que la influencia de programas de mejoría de la calidad puede considerarse como favorable sobre el ambiente de práctica profesional de enfermería. También aporta contribuciones para la gestión en la implantación de estrategias objetivando a la mejoría continua de las características del ambiente.

Descriptores: Enfermería; Calidad de la Asistencia a la Salud; Acreditación Hospitalaria; Ambiente Laboral; Mejoría de Calidad. 


\section{INTRODUCTION}

The search for health care quality is an ongoing concern of health institutions, which are increasingly investing in structural and organizational improvement, training their staff, and improving their work processes. The work environment is one of the primordial elements for the quality of health care, to develop a safe professional practice ${ }^{(1)}$.

The professional practice environment is defined as the presence of organizational characteristics that facilitate or not the development of the work process ${ }^{(2)}$. It is considered favorable when the professional demonstrates autonomy, control over the work environment, good relations with the multiprofessional team and, consequently, shows greater professional satisfaction and provides a great quality service. Surveys affirm that favorability in the nursing profession may positively impact the assistance offered to the patients safety, as well as reduce absenteeism, burnout e turnover ${ }^{(1,3-4)}$.

The development of professional autonomy, control over the work environment and organizational support may vary according to each institution, as well as the interpersonal relations with the multiprofessional staff. These components are essential to contextualize the environment. Therefore, health care organizations are constantly seeking conditions and programs that help to improve, maintain and monitor the environment in view of the impact on the quality of service ${ }^{(4)}$.

For Donabedian ${ }^{(5)}$, health quality is the achievement of values that ensure lower risks for the customer, obtained according to available resources and existing social values. For the author, the concept of quality is better understood with the support of seven pillars: "efficacy, productivity, optimization, acceptability, legitimacy, and equity". The proposed model of analysis and promotion is based on three pillars, known as triad: structure, corresponding to the necessary conditions (physical, human, financial and material resources) for the development of the assistance process; process, referring to the care activities; and result, corresponding to the effects and consequences of the interventions.

Consequently, one can think of a model of professional nursing practice characterized by systems instrumentalizing nurses in health care and composed of structure, processes and values, subdivided into: management system (considering structure and processes applied for decision making), health care service system, professional relationship, remuneration and professional values ${ }^{(4)}$.

In view of the importance of evaluating the environment of professional nursing practice to determine the satisfaction of the professional, which directly affects the quality of the assistance provided, it is understood that is needed further deepening in this area through an integrative review.

\section{OBJETIVES}

To analyze the knowledge produced regarding the practice environment in hospitals with quality improvement programs.

\section{METHODS}

The present article is an integrative review of the literature, developed with the purpose of synthesizing the main findings of primary articles from surveys that used different methodologies, enabling the analysis, and deepening knowledge on the proposed theme.
The survey permeated six stages for its execution: 1) definition of the theme and elaboration of the guiding question; 2) determination of inclusion and exclusion criteria for search in the literature; 3) data collection defining the selected surveys; 4) critical analysis of the included surveys; 5 ) discussion of the results; 6 ) presentation of the integrative review ${ }^{(6-7)}$.

For the first stage, it was chosen the use Patient/population, Intervention or issue of interest, Comparison intervention or issue of interest, Outcomes and Time (PICOT) $)^{(8)}$ as a strategy to elaborate the guiding issue, because represented the essential elements that would guide an adequate research and a correct definition of the evidence to be clarified $^{(9)}$. The $C$ and T components were not used since the survey is not intended to make comparisons and there is no publication period to be stipulated in the analysis of this research. As presented in Chart 1 , the constituent elements of the guiding question and representatives of the strategy ${ }^{(8-9)}$ behave as PIO. Thus, the guiding question was defined: Do hospital quality improvement programs influence the environment of the professional nursing practice?

Chart 1 - Representation of strategy Patient/population, Intervention or issue of interest, Comparison intervention or issue of interest, Outcomes e Time ${ }^{(8-9)}$

\begin{tabular}{|c|c|c|c|}
\hline Definition & Proposal & $\begin{array}{l}\text { Descriptors } \\
\text { DeCs / MeSH }\end{array}$ & Keywords \\
\hline $\begin{array}{l}\text { P-Patient/ } \\
\text { population }\end{array}$ & $\begin{array}{l}\text { Nursing } \\
\text { working in } \\
\text { hospitals }\end{array}$ & $\begin{array}{l}\text { Nursing staff; } \\
\text { Hospital / } \\
\text { Nursing, Team; } \\
\text { Team Nursing; } \\
\text { Hospitals }\end{array}$ & $\begin{array}{l}\text { Nursing; } \\
\text { Nursing } \\
\text { professionals; } \\
\text { Hospital }\end{array}$ \\
\hline $\begin{array}{l}\text { I- Intervention } \\
\text { or issue of } \\
\text { interest }\end{array}$ & $\begin{array}{l}\text { Hospital quality } \\
\text { improvement } \\
\text { programs }\end{array}$ & $\begin{array}{l}\text { Accreditation; } \\
\text { Hospital } \\
\text { accreditation; } \\
\text { Quality of health } \\
\text { care; Quality } \\
\text { management/ } \\
\text { Accreditation; } \\
\text { Quality of } \\
\text { Health Care; } \\
\text { Total Quality } \\
\text { Management; } \\
\text { Management, } \\
\text { Total Quality }\end{array}$ & $\begin{array}{l}\text { Accreditation } \\
\text { Program; } \\
\text { Quality of } \\
\text { Health Care }\end{array}$ \\
\hline O-Outcomes & $\begin{array}{l}\text { Favourable or } \\
\text { unfavourable } \\
\text { nursing practice } \\
\text { environment }\end{array}$ & $\begin{array}{l}\text { Ambiente de } \\
\text { trabalho / } \\
\text { Workplace }\end{array}$ & $\begin{array}{l}\text { Nursing work } \\
\text { environment }\end{array}$ \\
\hline
\end{tabular}

Note: DeCS - Descritores da Ciência da Saúde; MeSH - Medical Subject Headings.

For the search and selection of articles it has been used the Latin American and Caribbean Literature in Health Sciences (BVS LILACS), US National Library of Medicine/National Institutes of Health (PubMed/MEDLINE), Web of Science, Scopus and CINAHL databases during January and February, 2019. Controlled descriptors were used in DeCS (Health Science Descriptors) and keywords; and to perform the crossing between terms, the Boolean logical operators AND (restrictive) and OR (additive) ${ }^{(9)}$.

Inclusion criteria were: original surveys, entirely available, published in Portuguese, English and Spanish, in national and international journals, with the application of a term of consent and validated instruments in the nursing staff at hospitals which have a consolidated quality 
improvement program. And the exclusion criteria were: articles that, although they reported the professional nursing practice environment, did not measure favorability; and instruments validation articles.

To data collection, it was decided to used a tool developed by the authors, including: identification of the article, authors, place of survey and publication, journal, year of publication, objectives, method, data collection instrument, research outline, main results and conclusions ${ }^{(6)}$. Subsequently, a bibliometric analysis ${ }^{(10)}$ of the sample was performed, considering the levels of evidence, from I to VII, as described by Galvão (2006) ${ }^{(11)}$ :

Level 1, evidence comes from a systematic reviews or meta-analysis of all relevant randomized controlled clinical trials or from clinical guidelines based on systematic reviews of randomized controlled clinical trials; level 2, evidence derived from a single well-designed randomized controlled clinical trial; level 3 , evidence obtained from well-designed non-randomized controlled trials; level 4, evidence from well-designed cohort ande case-control studies; level 5, evidence from systematic reviews of descriptive and qualitative studies; level 6, evidence derived from a single descriptive or qualitative study; level 7, evidence from the opinions of authorities and/or reports of expert committee.

The results were presented in charts containing the synthesis of research findings which composed the review. To discuss data, they were assembled into thematic categories based on content analysis proposed by Bardin ${ }^{(12)}$, resulting in the discussion and final synthesis of the knowledge obtained.

\section{RESULTS}

Initially, the search raised 9,295 articles. After reading titles and abstracts, 15 complete text articles were selected to be entirely evaluated, but 5 were excluded due to exclusion criteria, so a sample of 10 articles was established to compose this survey, as represented in Figure 1.

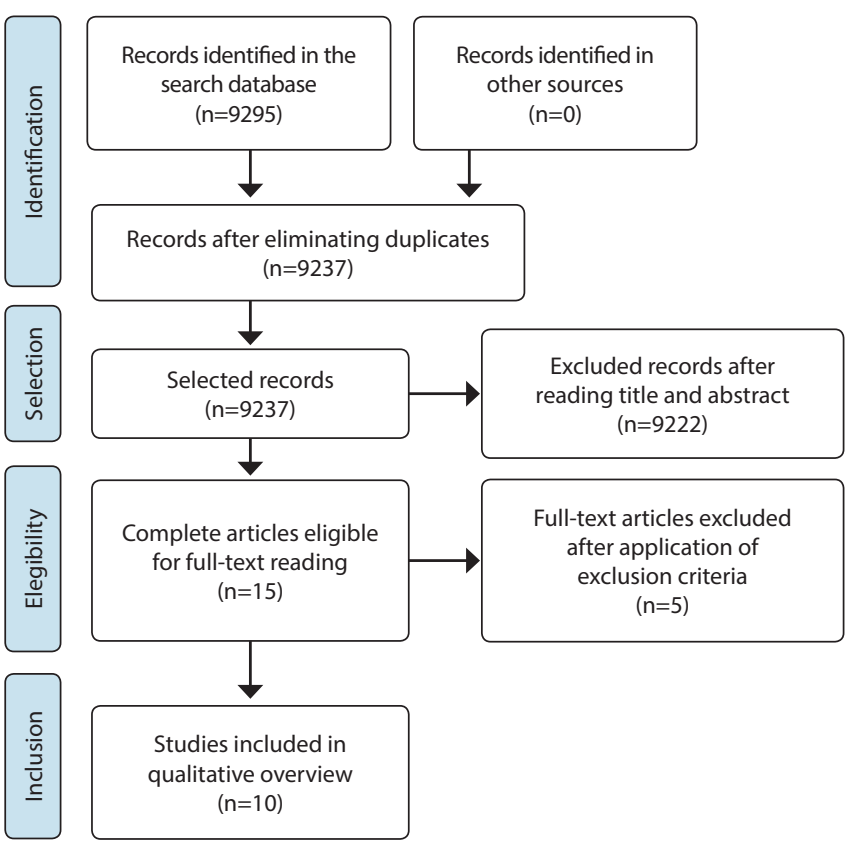

Figure 1 - Flowchart showing the identification process, selection and inclusion of articles, based on the Preferred Reporting Items for Systematic Review and Meta-Analyses (PRISMA) ${ }^{(13)}$
The bibliometric analysis (Chart 2) showed that seven (70\%) of the selected articles were published in the last five years, being 2016 the year with the highest number of publications (30\%). As for the country of survey, Brazil stood out with four surveys (40\%), and the others (60\%) were conducted in Australia (10\%), Canada (10\%), China (10\%), United States (10\%), Japan (10\%), and Israel (10\%). All selected articles were published in different journals. Regarding the survey methods, there was predominance in the quantitative approach (90\%); and one (10\%) of sequential explanatory combined method. As for the level of evidence, all are at level $\mathrm{VI}$, i.e., descriptive surveys.

Chart 2 - Bibliometric analysis of the articles

\begin{tabular}{|c|c|c|c|}
\hline Article & $\begin{array}{l}\text { Title of Journal/ } \\
\text { Journal Impact } \\
\text { factor or Citescore } \\
2018\end{array}$ & $\begin{array}{l}\text { Country of survey/ } \\
\text { Year of publication }\end{array}$ & $\begin{array}{c}\text { Research } \\
\text { Outline/ Level } \\
\text { of evidence }\end{array}$ \\
\hline$A 1^{(14)}$ & $\begin{array}{l}\text { Acta Paulista de } \\
\text { Enfermagem/ 0,5814 }\end{array}$ & Brazil/ 2016 & $\begin{array}{c}\text { Transversal, } \\
\text { quantitative / Vl }\end{array}$ \\
\hline$A 2^{(15)}$ & $\begin{array}{l}\text { Revista Gaúcha de } \\
\text { Enfermagem/ 0,5493 }\end{array}$ & Brazil/ 2016 & $\begin{array}{c}\text { Transversal, } \\
\text { descriptive, } \\
\text { quantitative/VI }\end{array}$ \\
\hline$A 3^{(16)}$ & $\begin{array}{l}\text { The Journal } \\
\text { of Nursing } \\
\text { Administration/ 0,49 }\end{array}$ & Australia/ 2014 & Quantitative/Vl \\
\hline$A 4^{(17)}$ & $\begin{array}{l}\text { International Journal } \\
\text { of Health Care } \\
\text { Quality Assurance } \\
\text { Incorporating } \\
\text { Leadership Health } \\
\text { Services/ } 0,72\end{array}$ & Canada/ 2004 & Quantitative/Vl \\
\hline$A 5^{(18)}$ & $\begin{array}{l}\text { Medical Science } \\
\text { Monitor/ 1,98 }\end{array}$ & China/ 2017 & $\begin{array}{c}\text { Historical } \\
\text { control study, } \\
\text { quantitative / VI }\end{array}$ \\
\hline$A 6^{(19)}$ & $\begin{array}{l}\text { AACN Advanced } \\
\text { Critical Care/ 1,04 }\end{array}$ & United States/ 2017 & $\begin{array}{c}\text { Transversal, } \\
\text { quantitative/VI }\end{array}$ \\
\hline$A 7^{(20)}$ & $\begin{array}{l}\text { Nursing and Health } \\
\text { Sciences/ 1,321 }\end{array}$ & Japan/ 2014 & Quantitative/Vl \\
\hline$A 8^{(21)}$ & $\begin{array}{l}\text { Journal of Nurse } \\
\text { Nursing Care Quality/ } \\
1,191\end{array}$ & Israel/ 2016 & Quantitative/VI \\
\hline$A 9^{(22)}$ & $\begin{array}{l}\text { Escola Anna } \\
\text { Nery Revista de } \\
\text { Enfermagem/ 1,0249 }\end{array}$ & Brazil/ 2018 & $\begin{array}{l}\text { Combined } \\
\text { explanatory } \\
\text { sequential } \\
\text { method / VI }\end{array}$ \\
\hline $\mathrm{A} 10^{(23)}$ & Einstein/ 0,1040 & Brazil/ 2018 & Quantitative/Vl \\
\hline
\end{tabular}

Regarding the type of instrument used to measure the practice environment, six (60\%) used the Nursing Work Index - Revised (NWI-R); three (30\%), the Practice Environment Scale (PES); and one (10\%), the Healthy Work Environment Assessment (HWEA) - as shown in Chart 3. Regarding the population studied, three surveys (30\%) applied the instruments to the entire nursing team and the others (70\%) to the nurses. 
Chart 3 - Summary of articles according to improvement program, data collection tool, population, and outcome on practice environment

\begin{tabular}{|c|c|c|c|}
\hline Article & $\begin{array}{c}\text { Improvement } \\
\text { program }\end{array}$ & $\begin{array}{l}\text { Environmental } \\
\text { assessment tool / } \\
\text { Population }\end{array}$ & $\begin{array}{l}\text { Results and Outcome on } \\
\text { the Practice Environment }\end{array}$ \\
\hline $\mathrm{A} 1^{(14)}$ & $\mathrm{ONA}^{*}$ & $\begin{array}{l}\text { NWI-R }{ }^{\dagger} / 106 I I U^{\ddagger} \\
\text { nurses, two public } \\
\text { hospitals }\end{array}$ & $\begin{array}{l}\text { Favorable environments. } \\
\text { Autonomy averaged } 2.0 \text { in } \\
\text { both. Accreditation did not } \\
\text { interfere with the result. }\end{array}$ \\
\hline$A 2^{(15)}$ & $\mathrm{JCl}^{\S}$ & $\begin{array}{l}\mathrm{NWI}-\mathrm{R}^{\dagger} / 136 \mathrm{IU}^{\ddagger} \text { and } \\
\mathrm{ICU} \text { nursing staff }\end{array}$ & $\begin{array}{l}\text { Favorable environment. } \\
\text { Relationship between } \\
\text { doctors and nursing with } \\
1.93 \text { and Autonomy with } \\
1.99 \text {. }\end{array}$ \\
\hline$A 3^{(16)}$ & $\begin{array}{l}\text { Magnet } \\
\text { Certificate }^{\circ}\end{array}$ & $\begin{array}{l}\text { PES" Australia/ } 492 \\
\text { nursing staff }\end{array}$ & $\begin{array}{l}\text { Favorable environment. } \\
\text { Quality nursing } \\
\text { fundamentals of care } \\
\text { with 3.18, Unit manager } \\
\text { capacity, leadership and } \\
\text { support of nurses with } 3.09 .\end{array}$ \\
\hline $\mathrm{A} 4^{(17)}$ & $\begin{array}{c}\text { Canadian } \\
\text { Accreditation }\end{array}$ & NWI-R ${ }^{\dagger} / 246$ nurses & $\begin{array}{l}\text { Favorable environment. } \\
\text { Adequacy of personnel and } \\
\text { resources with } 2.03, \text { but } \\
\text { the relationship between } \\
\text { nurse and doctor showed } \\
\text { weakness, with } 2.79 \text {. }\end{array}$ \\
\hline $\mathrm{A} 5^{(18)}$ & $\mathrm{JCl}^{\S}$ & $\begin{array}{l}\text { PES" China/ } 1.085 \\
\text { nurses }\end{array}$ & $\begin{array}{l}\text { Favorable environment. } \\
\text { Item Internal relationship } \\
\text { and autonomy, best } \\
\text { evaluated, with 3.27, } \\
\text { followed by Motivation } \\
\text { with } 3.22 \text {. }\end{array}$ \\
\hline$A 6^{(19)}$ & $\begin{array}{l}\text { Magnet } \\
\text { Certificate }^{\circ}\end{array}$ & $\begin{array}{l}\text { HWEA }^{* *} / 105 \text { ICU } \\
\text { nurses" }\end{array}$ & $\begin{array}{l}\text { Good atmosphere. Effective } \\
\text { decision making was } \\
\text { best evaluated with } 3.72 \text {, } \\
\text { followed by Authentic } \\
\text { Leadership with } 3.71 \text {. }\end{array}$ \\
\hline$A 7^{(20)}$ & $\begin{array}{l}\text { Japanese } \\
\text { Certification }\end{array}$ & $\begin{array}{l}\text { PES" Japan/ } 223 \text { ICU } \\
\text { nurses"l }\end{array}$ & $\begin{array}{l}\text { Favorable environment. } \\
\text { Relationship between } \\
\text { doctor and nurse with } \\
2.84 ; \text { Capacity of nursing } \\
\text { manager, leadership, and } \\
\text { support of nurses with } 2.82 \text {. }\end{array}$ \\
\hline$A 8^{(21)}$ & $\mathrm{JCl}^{\S}$ & NWI-R ${ }^{\dagger} / 363$ nurses & $\begin{array}{l}\text { Unfavorable environment. } \\
\text { After accreditation, } \\
\text { averages increased in all } \\
\text { variables, with Control over } \\
\text { Practice being the best } \\
\text { evaluated with } 3.64 \text {. }\end{array}$ \\
\hline$A 9^{(22)}$ & $\mathrm{ONA}^{*}$ & $\begin{array}{l}\text { NWI-R }{ }^{+} / 226 \text { ICUII } \\
\text { nursing staff, three } \\
\text { hospitals }\end{array}$ & $\begin{array}{l}\text { Favorable environments. } \\
\text { Even with the } 1.88 \text { medical- } \\
\text { nurse relationship at } \\
\text { the accredited hospital, } \\
\text { accreditation did not } \\
\text { interfere with the result. }\end{array}$ \\
\hline $\mathrm{A} 10^{(23)}$ & $\mathrm{ONA}^{*}$ & $\begin{array}{l}\text { NWI- } \mathrm{R}^{\dagger} / 188 \text { nurses, } \\
\text { four hospitals }\end{array}$ & $\begin{array}{l}\text { The accreditation favored } \\
\text { the environment. Averages } \\
\text { close to } 2.0 \text { in the domains. } \\
\text { However, } 62.2 \% \text { of the total } \\
\text { indicated a lack of staff and } \\
\text { overload as detractors. }\end{array}$ \\
\hline
\end{tabular}

Note: ${ }^{*}$ ONA - National Accreditation Organization; ${ }^{\dagger} N W I-R$ - Nursing Work Index - Revised; ${ }^{\ddagger} I U$ Inpatient Unit; ${ }^{5} \mathrm{JCl}$ - Joint Commission International; "ICU - Intensive Care Unit; "PES - Practice Environment Scale; **HWEA - Healthy Work Environment Assessment.

\section{DISCUSSION}

\section{Measures for the environment of professional nursing practice}

The evaluation of the professional nurse practice environment was the target of analysis in all surveys, connecting that data to an upgrade program implemented in hospitals. Consequently, it is observed that the search for quality in health care services and standards of excellence are recognized in several countries; to this end, health care institutions seek tools and programs that can assist and positively intervene in direct care and in the process management to ensure safety and a better experience for the patient.

Of ten surveys composing the review, three ${ }^{(15-16,22)}$ applied questionnaires to the entire nursing staff, which two of them ${ }^{(16,22)}$ were conducted in Brazil; in the other the questionnaire were only applied to nurses. This finding makes us reflect on the importance of investigating the environment for all nursing professionals: due to the class professional power structure, the direct leader of the assistants and technicians is unit's nurse, who, in turn, is led by a higher management. These different leaderships may influence by generating multiple perceptions of the same practice environment.

In all surveys, the practice environment was evaluated using scale-based instruments ${ }^{(14-23)}$, such as NWI-R, PES and HWEA. We will address each one below.

The NWI-R derived from the Nursing Work Index (NWI), it is the most applied instrument in different cultures and practice environments and has already been translated and adapted to various locations around the world. It consists of 57 items arranged in four sub-scales: autonomy, control over the work environment, relationship between nurse and physicians and organizational support ${ }^{(14-15,17,22-24)}$.

In 2002, the NWI-R was revised generating a new version known as PES, with the same objective of evaluating the professional nurse practice environment. It consists of 31 items structured in five sub-scales: nurse participation in hospital affairs, nursing fundamentals in quality of care, nurse leadership management, adequacy of human resources in quality of care and collegiate relations between nurses and physicians ${ }^{(16,18,20,25)}$. Both NWI-R and PES assess characteristics using a Likert scale with scores from 1 to 4 , but differ in the mode of evaluations: in NWI-R, averages below 2.5 indicate a favorable environment; in PES, the higher the score, the higher the favorability ${ }^{(24-25)}$.

The HWEA was developed in 2009 by the American Association of Critical Nurses (AACN) as a resource to assess the status and progress of a hospital's journey in order to implement and maintain the necessary standards, because the leaders stated that in order to ensure quality care services, it is essential to be focused on the performance of the health staff. Composed of 18 questions that evaluate six standards of a healthy practice environment, it uses the Likert scale of five points to indicate the level of agreement and should be evaluated on average: 4 to 5 is excellent; 3 to 3.99 is good; and 1 to 2.99 is considered to need improvement ${ }^{(26)}$.

\section{Hospital Accreditation as an improvement program}

Hospital Accreditation was pointed out as an effective intervention for assistance improvement in seven surveys, and $\mathrm{JCl}$ and 
ONA were the most present accreditation institutions, with three surveys in each institution, followed by Canadian Accreditation with one survey. It is also important to emphasize that in two surveys $^{(16,19)}$, the Magnet ${ }^{\circ}$ Certification was consolidated in the hospitals, demonstrating the recognition of the magnet program.

An accredited institution is seen as a symbol of quality and high standards of management and assistance, ensuring its space and recognition within the list of institutions of excellence/gold standard. Accreditation programs provide a range of assessments based on classical quality management principles and management strategies, systematically leading to improvements in the health care service $\mathrm{e}^{(14-15,22-23)}$.

Meeting the need for the implementation of certifications, nursing, as a fundamental member of the multiprofessional staff, also seeks to establish certifications that promote the continuous improvement of their practices and consequently patient safety. In that sense, the Magnet Recognition Program stands out, which was presented in two analyzed surveys. This program certifies and recognizes nursing service as a service of excellence in its practices and strategies, and also reflecting on the quality and safety of the user and satisfaction in care ${ }^{(16,27)}$. This evaluation is based on five components from the ideal model:"transformational leadership; empowerment structure; exemplary professional practice; new knowledge, innovations, and improvements; and, at last, empirical results in quality"(27). Magnet ${ }^{\circ}$ certified services are recognized for attracting and retaining nursing professionals, due to the appreciation of the category ${ }^{(16,19,27)}$.

\section{Nursing autonomy, interpersonal relationship between nurse and physicians and nurse as manager and leader}

Among the aspects evaluated in the surveys, stands out the autonomy of the nursing professional ${ }^{(14-15,18-19,21)}$ in relation to his/ hers attributions and competencies within the environment. Have the opening to perform this role in a healthy manner and with the support from a leadership favors the development of skills, reasoning, empowerment, control over practice and professional responsibility ${ }^{(28)}$. As a support to the development of autonomy, the survey ${ }^{(18)}$ points out the role of continuing education as essential in order to act with the institution's managers in the educational training, continuously qualifying their professionals for this job.

Having autonomy in caring and participating in the decisionmaking process favors to narrow the relations between administrator and employees and, in turn, makes employees feel to be an important member of the team, increasing their satisfaction. Another survey ${ }^{(19)}$ addresses significant recognition as a tool that contributes to training and promotes nurse retention. It is essential to carry on creative approaches focusing on professional's personal demand and working in a collective power, in order to develop an effective communication between the parties and reduce professional's performance in a forced work environment.

Therefore, surveys ${ }^{(16,18-20,22)}$ point out that the participation of an authentic, strongly present and capable leadership provides support and encouragement to other nursing professionals, boosting confidence to act in their environment, because the leaders are seen as mirrors and their actions impact directly on the subordinates. These surveys highlight that the involvement of the administration with the staff in the control of the practice environment enables a promotion of practices to improve the quality of health care.

Another point interfering with the work dynamics and quality of care is the relationship between health professionals ${ }^{(29)}$. In the analyzed surveys, four discussed the relationship between physicians and nurses and identified that when they act in an integrated manner while delivering a qualified and ethical care, such positive interaction provides a favorable practice environment to all members ${ }^{(15,17,20,22)}$.

Based on the analysis of the surveys, it is understood that there is a consensus that the accreditation of hospital institutions has a positive impact on the professional nursing practice environment, but it is possible to observe that such process calls for an organizational movement linked to bureaucratic issues and the need to seek innovations in order to meet the demand for market competitiveness and to achieve levels of excellence in the quality of care. However, this movement may generate work overload and tension for those involved, triggering moral suffering and dissatisfaction ${ }^{(14-15,23)}$. Such findings offer information so that the practice environment in the institutions are periodically evaluated and, based on the results, improvement actions will be monitored in order to develop a healthy environment.

\section{Study limitations}

The objective of this survey was to analyze the professional nursing practice environment in hospitals that have consolidated quality improvement programs, but there are few published surveys describing this information on the studied institutions, which limited the findings during the search. Another limitation point was the publication of unfavorable results due to the concern of institutions which could possibly ended up being labeled in the market.

\section{Contributions to the Nursing field}

Although the discussion about the importance of implementing quality improvement programs is currently broad and increasing, little is debated about how those programs and their whole process can influence the nursing practice environment in both private and public or philanthropic institutions. Such influence may not only generate conflict and dissatisfaction but may also be positive in causing the institution to retain its staff because they provide a satisfactory and favorable environment for nursing professional evolution. There is still a gap to be filled by research (mainly national) on this topic, and it is also necessary to enrich the debates.

\section{FINAL CONSIDERATIONS}

The research made it possible to analyze the influence of quality improvement programs on the professional nursing practice environment. Although two surveys pointed out that there was no significant interference in the results, it is possible that the implementation of these programs could be considered favorable. Evaluation by instruments helped us to survey elements and detect situations which may help the administration to implement strategies for continuous improvement of the environment characteristics, favoring the development of the activities, better satisfaction, and retention of nursing professionals. 


\section{REFERENCES}

1. Cuduro FLF, Macedo SMK. Evaluation of the working environment between nursing professionals in na urgente and emergency unit. Enferm Global. 2018;(50):375-387. doi: 10.6018/eglobal.17.2.283991

2. Gasparino RC, Guirardello EB. Validation of the Practice Environment Scale to the Brazilian culture. J Nurs Manag. 2017;25(5):375-83. doi: 10.1111/jonm.12475

3. Dorigan GH, Guirardello EB. Nursing practice environment, satisfaction and safety climate: the nurses' perception. Acta Paul Enferm. 2017;30(1):129-35. doi: 10.1590/1982-0194201700021

4. Maurício LFS, Okuno MFP, Campanharo CRV, Lopes MCBT, Belasco AGS, Batista REA. Prática profissional do enfermeiro em unidades críticas: avaliação das características do ambiente de trabalho. Rev Latino-Am. Enfermagem. 2017;25;e2854. doi: 10.1590/1518-8345.1424.2854

5. Donabedian A. An introduction to quality assurance in Health Care. Oxford: University Press; 2003. 240p.

6. Mendes KDM, Silveira, Silveira RCC, Galvão MC. Integrative literature review: a research method to incorporate evidence in health care and nursing. Texto Contexto Enferm. 2008;17(4):758-64. doi: 10.1590/S0104-07072008000400018

7. Botelho LLR, Cunha CCA, Macedo M. The integrative review method in organizational studies. Gestão Soc. 2011;5(11):121-36. doi: 10.21171/ ges.v5i11.1220

8. Santos CMC, Pimenta CAM, Nobre MRC. The PICO strategy for the research question construction and evidence search. Rev Latino-Am Enfermagem. 2007;15(3):508-11. doi: 10.1590/S0104-11692007000300023

9. Esteves LSF, Cunha ICKO, Bohomol E, Negri EC. Supervised internship in undergraduate education in nursing: integrative review. Rev Bras Enferm. 2018;71(4):1740-50. doi: 10.1590/0034-7167-2017-0340

10. Medeiros IL, Vieira A, Braviano G, Gonçalves BS. Canvas for Systematic review and Bibliometrics: literatura review facilitated by information visualization. Rev Bras Design Inform. 2015 [cited 2019 Feb 10];12(1):93-110. Available from: https://www.infodesign.org.br/infodesign/ article/viewFile/341/213

11. Galvão CM. Níveis de evidência. Acta Paul Enferm. 2006;19(2):5. doi: 10.1590/S0103-21002006000200001

12. Bardin L. Análise de conteúdo. Lisboa, Portugal: Edições 70, LDA; 2009.

13. Moher D, Liberati A, Tetzlaff J, Altman DG. Preferred reporting items for systematic reviews and meta analyses: the PRISMA statement. BMJ. 2009;339:b2535. doi: 10.1371/journal.pmed.1000097

14. Oliveira PB, Spiri WC, Dell'Acqua MCQ, Mondini CCSD. Comparison between the accredited and non-accredited public hospital working environments. Acta Paul Enferm. 2016; 29(1):53-9. doi: 10.1590/1982-0194201600008

15. Alves DFS, Guirardello EB. Nursing work environment, patient safety and quality of care in pediatric hospital. Rev Gaúcha Enferm. 2016;37(2):e58817. doi: 10.1590/1983-1447.2016.02.58817

16. Walker K, Fitzgeral K, Duff J. Supporting a healthy culture: results of the Practice Environment Scale, Australia in a Magnet Designated Hospital. J Nurs Adm. 2014; 44(12):653-8. doi: 10.1097/NNA.0000000000000143

17. McCsker J, Dendukuri N, Cardinal L, Laplante J, Bambonye L. Nursing work environment and quality of care: diferences between units at the same hospital. Int J health Care Qual Assur Inc Leadersh Health Serv. 2004;17(6):313-22. doi: 10.1108/09526860410557561

18. Liu J, Zhou H, Yang X. Evaluation and improvement of the nurse satisfactory status in a tertiary hospital using the professional practice environment scale. Med Sci Monit. 2017;23:874-80. doi: 10.12659/msm.902249.

19. Kelly L, Todd M. Compassion Fatigue and the Healthy Work Environment. AACN Adv Crit Care. 2017;26(4):351-8. doi: 10.4037/ aacnacc2017283

20. Anzai E, Douglas C, Bonner A. Nursing practice environment, quality of care, and morale of hospital nurses in Japan. Nurs Health Sci. 2014;16(2):171-8. doi: 10.1111/nhs.12081

21. Kagan I, farkash-Fink N, Fish M. Effect of Joint Commission International Accreditation on the Nursing Work Environment in a Tertiary Medical Center. J Nurs Care Qual. 2016;00(00):1-8. doi: 10.1097/NCQ.0000000000000180

22. Oliveira JLC, Souza VS, Pereira ACS, Fernandez MC, Haddad L, Marcon SS, et al. Work environment and accreditation: analysis by mixed explanatory sequential method. Esc Anna Nery. 2018; 22(4):e20170379. doi: 10.1590/2177-9465-ean-2017-0379

23. Pires BSM, Oliveira LZF, Siqueira CL, Feldman LB, Oliveira RA, Gasparino RC. Nurse work environment: comparison between private and public hospitals. Einstein. 2018;16(4):1-6. doi: 10.31744/einstein_journal/2018AO4322

24. Nogueira LS, Sousa RMC, Guedes ES, Santos MA, Turrini RNT, Cruz DALM. Burnout and nursing work environment in public health institutions. Rev Bras Enferm. 2018;71(2):358-65. doi: 10.1590/0034-7167-2016-0524

25. Azevedo Filho FM, Rodrigues MCS, Cimiotti JP. Nursing practice environment in intensive care units. Acta Paul Enferm. 2018;31(2):2017.23. doi: 10.1590/1982-0194201800031

26. Connor JA, Ziniel Al, Porter C, Doherty D, Moonan M, Dwyer P, et al. Interprofessional use and validation of the AACN healthy work environment assessment tool. AACN Adv Crit Care. 2018;27(5):363-72. doi: 10.4037/ajcc2018179 
27. Parisi TCH, Melleiro MM. Magnet Recognition program: revisão integrativa de literatura. Rev Baiana Enferm. 2016;30(4):1-13. doi: 10.18471/ rbe.v30i4.16705

28. Santos El, Alves YR, Silva ACSS, Gomes AMT. Professional autonomy and nursing: representations of health professionals. Rev Gaucha Enferm. 2017;38(1):e59033. doi: 10.1590/19831447.2017.01.59033

29. Santos OS, Bernardes A, Vasconcelos RMA, Santos RS. Relationship between doctors and nurses from Cáceres Regional Hospital Dr. Antonio Fontes: a nurse's perspective. Rev Ciênc Estud Acad Med [Internet]. 2015 [cited 2020 Jan 10];(4):10-28.Available from: https://periodicos. unemat.br/index.php/revistamedicina/article/view/911/895 